\title{
Characterization of El Niño, La Niña, and normal conditions through planktonic foraminifera (2006-2007) in the southeastern Pacific
}

\section{Caracterización de El Niño, La Niña y condiciones normales a través de foraminíferos planctónicos (2006-2007) en el Pacífico suroriental}

\author{
Nathalie Gajardo ${ }^{1,2 *}$, Humberto E González ${ }^{3,4}$, Margarita Marchant ${ }^{1}$ \\ ${ }^{1}$ Departamento de Zoología, Universidad de Concepción, Casilla 160-C, Concepción, Chile. \\ 2 Programa de Magíster en Ciencias mención Zoología, Escuela de Graduados, Universidad de Concepción, \\ Casilla 160-C, Concepción, Chile. \\ ${ }^{3}$ Instituto de Ciencias Marinas y Limnológicas, Universidad Austral de Chile, Casilla 567, Valdivia, Chile. \\ ${ }^{4}$ Programa de financiamiento Basal, COPAS Sur-Austral, Universidad de Concepción, Casilla 160-C, \\ Concepción, Chile, and Centro de Investigaciones en Ecosistemas de la Patagonia (CIEP), Coyhaique, Chile. \\ * Corresponding author. E-mail: nathagajardo@udec.cl
}

\begin{abstract}
We conducted a study to characterize the foraminiferal association off south-central Chile under positive (January to December 2006), neutral (January to June 2007), and negative (July to September 2007) thermal anomalies, which coincided approximately with El Niño (EN), normal (NC), and La Niña (LN) conditions, respectively, using samples collected in a sediment trap located off Concepción at $2300 \mathrm{~m}$ depth. During the three environmental conditions, total species richness was 19, with 18 species present during EN, 14 during NC, and 14 during LN. Moreover, a typical association of subantarctic waters was observed during NC and LN, but not during EN, when we found a mixture of cold and warm water species as well as higher foraminiferal and calcium carbonate fluxes. However, diversity was very similar under the three conditions. We observed significant differences in foraminiferal and calcium carbonate fluxes between NC and EN, with higher values during the warm phase.
\end{abstract}

Key words: planktonic foraminifera, El Niño, La Niña, southeastern Pacific

RESUMEN. Se realizó un estudio para caracterizar la asociación foraminiferológica frente a las costas del centro-sur de Chile en condiciones de anomalías térmicas positivas (enero a diciembre de 2006), neutras (enero a junio de 2007) y negativas (julio a septiembre de 2007), las que coincidieron aproximadamente con condiciones El Niño (EN), normales (CN) y La Niña (LN), respectivamente, mediante muestras recolectadas en una trampa de sedimento ubicada frente a Concepción y a $2300 \mathrm{~m}$ de profundidad. Durante las tres condiciones ambientales, la riqueza de especies fue de 19, 18 de ellas estuvieron presentes durante EN, 14 durante CN y 14 durante LN. Además, se evidenció una asociación típica de aguas subantárticas durante $\mathrm{CN}$ y LN, mientras que durante EN, se encontró una mezcla de especies tanto de aguas frías como cálidas. Durante EN se presentaron mayores flujos de carbonato de calcio y de individuos. Sin embargo, la diversidad, fue muy similar en las tres condiciones. Se encontraron diferencias significativas en los parámetros de flujo de carbonato de calcio y flujo de individuos entre CN y EN; los mayores valores se presentaron durante la fase cálida.

Palabras clave: foraminíferos planctónicos, El Niño, La Niña, Pacífico suroriental.

\section{INTRODUCTION}

The Humboldt Current System (HCS) belongs to one of the regions of the Eastern Border Current Systems (EBCS), which correspond to the most productive oceanic areas in the world. This system consists of a northern current (the PeruChile Current) and a southern current (the Cape Horn Current) (Berger et al. 1989, Strub et al. 1998, Silva et al. 2009). Also, the Peru-Chile countercurrent flows from north to south and presents high biological productivity at a global scale (Shaffer et al. 1995, Silva et al. 2009).

The presence of coastal upwelling areas is a common characteristic of the EBCS (Hormazabal et al. 2001, Carr and Kearns 2003) given the effect of southerly and southwesterly

\section{INTRODUCCIÓN}

El Sistema de la Corriente de Humboldt (SCH) pertenece a una de las regiones de los Sistemas de Corrientes de Bordes Orientales (SCBO), que corresponden a las áreas oceánicas más productivas del mundo. Este sistema está conformado por una corriente hacia el norte (la corriente de Perú-Chile) y una hacia el sur (la corriente del Cabo de Horno) (Berger et al. 1989, Strub et al. 1998, Silva et al. 2009). Además, desplazándose de norte a sur se encuentra la contracorriente de Perú-Chile, que es de alta productividad biológica a escala global (Shaffer et al. 1995, Silva et al. 2009).

La presencia de áreas de surgencias costeras es una característica común de los SCBO (Hormazabal et al. 2001, Carr y 
winds on surface waters that cause cold, saline, and oxygenpoor subsurface waters to rise (Brandhorst 1963). These seasonal winds prevail in the central-southern area of Chile, mainly during the summer between September and April (Kelly and Blanco 1984, Cáceres 1992, Daneri et al. 2000). This seasonality causes changes in productivity, which has been detected and measured through the concentration of chlorophyll- $a$, establishing well-defined seasonal cycles with maximum levels during the summer months associated with the presence of winds and the upwelling of nutrient-rich waters (Thomas et al. 2001).

These oceanographic conditions in the HCS can be affected by the presence of El Niño/Southern Oscillation (ENSO). This event consists of a joint system that combines both atmospheric and oceanographic components (Rasmusson and Carpenter 1982) and experiments continuous cyclic structure changes generating interannual climate variability in a large part of the Tropical Pacific (Aceituno and Montecinos 1993); however, it has global climate impacts (Fernández et al. 2004, McLean et al. 2009). This variability is conditioned by the extreme phases corresponding to El Niño (EN) and La Niña (LN) events (Rutllant and Fuenzalida 1991). EN is an aperiodic event that produces a difference between the atmospheric pressures of the eastern and western borders of the Pacific Ocean. This causes the entry of warm tropical waters from Australasia into the American coastal areas, superimposing a layer of warm tropical water over the cold layer that provokes an increase in temperature and nutrient-poor upwelling events, and a descent of the thermocline to below 100-200 m depth (Ramage 1986, González et al. 1998, Escribano et al. 2004). On the contrary, LN is characterized by an unusual decrease in temperature of surface waters (Cantillanez et al. 2005). During this event the average sea level descends and the thermocline ascends approaching the surface (Rutllant 2004). In addition, upwelling events are more frequent than during normal conditions (NC) and are registered in greater longitudinal extensions from the coast into the ocean (Bello et al. 2004).

These environmental variations impact the feeding chains in a predictable manner (Tappan and Loeblich 1988) and can be detected by plankton organisms such as foraminifera. Planktonic foraminifera are unicellular organisms possessing a carbonated shell (Boltovskoy 1965). They are usually used as bioindicators of ecological changes because they are sensitive to environmental variations such as seasonal fluctuations associated with phytoplankton maxima (Marchant et al. 1998, 2004).

In Chile, EN events have been characterized using planktonic foraminifera (Marchant et al. 1998, 2004; Hebbeln et al. 2000; Coloma et al. 2005), whereas LN studies are scarce. Only the study carried out by Marchant et al. (2004) off the coast of Coquimbo $\left(30^{\circ} \mathrm{S}\right)$ examines the variability of planktonic foraminiferal flux, obtaining data from the 1995-1996 LN event.
Kearns 2003) debido al efecto de los vientos del sur y suroeste sobre las aguas superficiales, que provoca el ascenso de aguas subsuperficiales frías, salinas y pobres en oxígeno (Brandhorst 1963). Estos vientos predominan de forma estacional en la zona centro-sur de Chile, principalmente durante la época estival entre septiembre y abril (Kelly y Blanco 1984, Cáceres 1992, Daneri et al. 2000). Esta estacionalidad provoca cambios en la productividad, que se ha detectado y medido mediante la concentración de clorofila- $a$, estableciéndose ciclos estacionales bien definidos con máximos durante los meses estivales asociados a la presencia de vientos y afloramientos de aguas ricas en nutrientes (Thomas et al. 2001).

Las condiciones oceanográficas en el SCH pueden verse afectadas debido a la presencia de El Niño/Oscilación del Sur (ENSO). Este evento conforma un sistema acoplado que combina componentes tanto atmosféricos como oceanográficos (Rasmusson y Carpenter 1982) y que experimenta cambios cíclicos continuos en su estructura generando una variabilidad climática interanual en gran parte del Pacífico tropical (Aceituno y Montecinos 1993); sin embargo, sus implicancias climatológicas son a nivel global (Fernández et al. 2004, Mc Lean et al. 2009). Esta variabilidad está condicionada por las fases extremas correspondientes a los eventos El Niño (EN) y La Niña (LN) (Rutllant y Fuenzalida 1991). El Niño es un evento aperiódico que produce una diferencia de presiones atmosféricas entre los bordes orientales y occidentales del océano Pacífico. Esto provoca el ingreso de aguas cálidas tropicales desde Australasia hasta las costas americanas, superponiéndose una capa de agua cálida de origen tropical sobre la capa fría que provoca un aumento en la temperatura, eventos de surgencia pobres en nutrientes y un descenso en la termoclina por debajo de los 100-200 m de profundidad (Ramage 1986, González et al. 1998, Escribano et al. 2004). Contrariamente, LN se caracteriza por un enfriamiento inusual de las aguas superficiales (Cantillanez et al. 2005). Durante este evento, el nivel del mar promedio desciende y la termoclina asciende, acercándose a la superficie (Rutllant 2004). Además, las surgencias son más frecuentes que en condiciones normales $(\mathrm{CN})$ y se registran en mayores extensiones longitudinales desde la costa hacia el océano (Bello et al. 2004).

Estas variaciones ambientales, impactan las cadenas alimentarias en forma predecible (Tappan y Loeblich 1988) y pueden ser detectadas por organismos del plancton como los foraminíferos. Los foraminíferos son organismos unicelulares que poseen una conchilla carbonatada (Boltovskoy 1965). Usualmente se les utiliza como bioindicadores de cambios ecológicos, ya que son sensibles a variaciones ambientales como, por ejemplo, fluctuaciones estacionales asociadas a los máximos de fitoplancton (Marchant et al. 1998, 2004).

En Chile, el evento EN se ha caracterizado mediante foraminíferos planctónicos (Marchant et al. 1998, 2004; Hebbeln et al. 2000; Coloma et al. 2005), mientras que los estudios sobre LN son escasos. Únicamente el trabajo de Marchant 
Gajardo et al.: Planktonic foraminifera as a proxy for oceanographic conditions in the southeastern Pacific

Marchant et al. (1998) documented the presence of 19 species during the 1991-1992 EN event and 17 species during NC off Coquimbo. In this same area, Coloma et al. (2005) registered 26 species during the 1997-1998 EN event. Marchant et al. (1998) identified Neogloboquadrina incompta, Globigerina bulloides, Neogloboquadrina pachyderma, Globigerinella calida, and Neogloboquadrina dutertrei as the most abundant species during the EN event. The average foraminiferal flux was $\sim 4000$ ind $\mathrm{m}^{-2} \mathrm{~d}^{-1}$ during $\mathrm{NC}$, decreasing slightly to 3000 ind $\mathrm{m}^{-2} \mathrm{~d}^{-1}$ during EN. The maximum levels of specimen flux coincided with an increase in coastal upwelling events, as also indicated by the values of $\delta^{18} \mathrm{O}$ and the gradient of $\delta^{18} \mathrm{O}\left(\Delta \delta^{18} \mathrm{O}<0.3 \%\right)$ between G. bulloides and $N$. incompta. This technique is commonly used given the close relation between the stable oxygen isotopes of foraminiferal shells and the environment, where the isotopic signal is given by the characteristics of the water column, allowing the reconstruction of its temperature levels (Emiliani 1955, Shackleton 1967, Savin 1977). This isotopic value was used to evaluate the water column off the coast of Coquimbo, Chile, and a deep mixed layer (evidencing coastal upwelling events) was identified between November and March, and thermal stratification (without upwelling, with values outside the $\pm 0.3 \%$ o range) was observed beginning in March, coinciding with low foraminiferal flux (Marchant et al. 1998).

On the other hand, Watkins et al. (1998) established an increase in primary productivity evidenced by the foraminiferal composition (G. bulloides, Globorotalia menardii, Globigerinita glutinata, Pulleniatina obliquiloculata, and $N$. dutertrei) present in the tropical equatorial region during the LN event (late 1992). The presence of G. bulloides was also registered, indicating coastal upwelling (Cullen and Prell 1984, Marchant et al. 1998), which would correspond to the greatest faunal change documented in that study.

Marchant et al. (2004) established a weak seasonal pattern in calcium carbonate flux during the beginning of 1996 (LN), with maximum levels of $110 \mathrm{mg} \mathrm{m}^{-2} \mathrm{~d}^{-1}$ towards the end of winter and beginning of the austral summer. Maximum foraminiferal levels were observed during the summer months, reaching 17,500 ind $\mathrm{m}^{-2} \mathrm{~d}^{-1}$ in 1994 (NC) and a maximum of 9300 ind $\mathrm{m}^{-2} \mathrm{~d}^{-1}$ in 1995 (LN). Globigerina bulloides presented maximum levels of 12,000 ind $\mathrm{m}^{-2} \mathrm{~d}^{-1}$ during NC (1993-1994), 7000 ind $\mathrm{m}^{-2} \mathrm{~d}^{-1}$ during LN, and 6000 ind $\mathrm{m}^{-2} \mathrm{~d}^{-1}$ during EN.

Considering the above and the different impacts that can be caused by oceanographic conditions (EN, LN, and NC), the objectives of this study include characterizing and analyzing these remote oceanographic events based on the specific abundance, diversity, calcium carbonate flux, and specimen flux of planktonic foraminifera off central-southern Chile. et al. (2004) realizado frente a las costas de Coquimbo $\left(30^{\circ} \mathrm{S}\right)$ examina la variabilidad del flujo de foraminíferos planctónicos, obteniendo datos del evento LN 1995-1996.

Marchant et al. (1998) documentaron la presencia de 19 especies durante el evento EN 1991-1992 y 17 especies durante $\mathrm{CN}$ frente a Coquimbo. En esta misma área, Coloma et al. (2005) registraron 26 especies durante el evento EN 1997-1998. Marchant et al. (1998) identificaron a Neogloboquadrina incompta, Globigerina bulloides, Neogloboquadrina pachyderma, Globigerinella calida y Neogloboquadrina dutertrei como las especies más abundantes durante el evento EN. El flujo promedio de foraminíferos fue de $\sim 4000$ ind $\mathrm{m}^{-2} \mathrm{~d}^{-1}$ durante $\mathrm{CN}$ y disminuyó ligeramente a 3000 ind $\mathrm{m}^{-2} \mathrm{~d}^{-1}$ durante EN. Los máximos en el flujo de individuos coincidieron con un aumento en las surgencias costeras, tal como ha sido indicado también por los valores del $\delta^{18} \mathrm{O}$ y el gradiente de $\delta^{18} \mathrm{O}\left(\Delta \delta^{18} \mathrm{O}<0.3 \%\right.$ entre $G$. bulloides y $N$. incompta. Esta técnica es muy utilizada dada la estrecha relación que existe entre los isótopos estables de oxígeno de las conchillas de foraminíferos y el ambiente, en donde dicha señal isotópica está dada por las características de la columna de agua, permitiendo reconstituir los niveles térmicos de ésta (Emiliani 1955, Shackleton 1967, Savin 1977). Este valor isotópico se utilizó para evaluar la columna de agua frente a las costas de Coquimbo, Chile, y se identificó una capa de mezcla profunda (evidenciando eventos de afloramientos costeros) entre noviembre y marzo y, a partir de éste último mes, se observó una estratificación térmica (sin surgencias, con valores fuera del intervalo de $\pm 0.3 \%$ ), coincidente con bajos flujos de foraminíferos (Marchant et al. 1998).

Por otro lado, Watkins et al. (1998) establecieron un aumento en la productividad primaria evidenciado por la composición de foraminíferos (G. bulloides, Globorotalia menardii, Globigerinita glutinata, Pulleniatina obliquiloculata y Neogloboquadrina dutertrei) presentes en la zona ecuatorial tropical durante el evento LN (a fines de 1992). Además, se registró la presencia de G. bulloides, especie indicadora de surgencias costeras (Cullen y Prell 1984, Marchant et al. 1998), lo cual sería el mayor cambio faunístico documentado en ese trabajo.

Marchant et al. (2004) establecieron un patrón estacional débil en el flujo de carbonato de calcio durante el comienzo de 1996 (LN), con máximos de $110 \mathrm{mg} \mathrm{m}^{-2} \mathrm{~d}^{-1}$ a fines del invierno y a comienzos del verano austral. Estos autores observaron máximos flujos de foraminíferos durante los meses estivales que alcanzaron $\operatorname{los} 17,500$ ind $\mathrm{m}^{-2} \mathrm{~d}^{-1}$ en 1994 (CN) y un máximo de 9300 ind $\mathrm{m}^{-2} \mathrm{~d}^{-1}$ en 1995 (LN). Globigerina bulloides presentó niveles máximos de 12,000 ind $\mathrm{m}^{-2} \mathrm{~d}^{-1}$ durante $\mathrm{CN}$ (1993-1994), 7000 ind $\mathrm{m}^{-2} \mathrm{~d}^{-1}$ durante LN y 6000 ind $\mathrm{m}^{-2} \mathrm{~d}^{-1}$ durante EN.

Considerando lo anterior y los diferentes impactos que pueden llegar a tener las diferentes condiciones oceanografícas (EN, LN y CN), los objetivos de este estudio 


\section{MATERIALS AND METHODS}

The samples were obtained with a sediment trap located at $2300 \mathrm{~m}$ depth and 100 nautical miles off Concepción Bay $\left(36^{\circ} \mathrm{S} ; 74^{\circ} \mathrm{W}\right)$. They were collected between January and December 2006 (EN), between January and June 2007 (NC), and between July and September 2007 (LN). All the samples were extracted with a rotation rhythm of 18 days during all three conditions. A total of 36 samples were obtained: 21 during EN, 10 during $\mathrm{NC}$, and 5 during LN.

The process used to decrease bacterial growth, regulate salinity, and store the samples was that proposed by Fischer and Wefer (1991) (for more details see Marchant et al. 1998, Gajardo and Marchant 2012). In the laboratory the sample was divided twice using a splitter and one-fourth of the total was used.

The shells were individually collected from each wet sample using a Pasteur pipette, and were then washed and dried at room temperature. The foraminifera were divided into three size fractions: $>212,212-150$, and $150-63 \mu \mathrm{m}$. The $>150 \mu \mathrm{m}$ fractions were used to identify and obtain the frequencies of the species found. The smaller foraminifera were not used as they may induce error during identification. The taxonomic classification was carried out following the order proposed by Boltovskoy (1976), Loeblich and Tappan (1988), and Coloma et al. (2005). The planktonic foraminiferal flux was determined by the total amount of specimens (expressed in ind $\mathrm{m}^{-2} \mathrm{~d}^{-1}$ ). Finally, the shells were weighed (mg) so as to determine the foraminiferal calcium carbonate flux $\left(\mathrm{mg} \mathrm{m}^{-2} \mathrm{~d}^{-1}\right)$. Both parameters were calculated based on the number and weight of individuals, respectively, multiplied by two (collecting net size in $\mathrm{m}^{2}$ ) and divided by the number of rotation days (18 days).

To determine possible biases with respect to the richness found during each event given that the number of samples was not homogeneous under all three conditions, a rarefaction analysis was carried out based on abundance using repeated and random re-sampling of a group of $N$ specimens (Gotelli and Colwell 2001). For this the program BioDiversity-Pro v2 was used.

We used the Shannon-Wiener index (Krebs 1985), with the program PAST v2.10, to determine diversity given that this index prioritizes the richness and the abundance uniformity of the individuals of each species over dominance, which overestimates the more abundant species and thus lessens the importance of the more scarce species. To establish the statistical differences in the studied parameters between each event (EN, NC, and LN), we carried out an analysis of variance (ANOVA) or a non-parametric KruskalWallis test depending on the case. In both cases a significance level of 0.05 and $n-1$ degrees of freedom were applied using the program PAST v2.15. son caracterizar y analizar dichos eventos oceanográficos remotos a través de la abundancia específica, la diversidad, los flujos de carbonato de calcio y el flujo de individuos de foraminíferos planctónicos frente al centro-sur de Chile.

\section{MATERIALES Y MÉTODOS}

Las muestras fueron obtenidas con una trampa de sedimento ubicada a $2300 \mathrm{~m}$ de profundidad y a 100 millas náuticas frente a la bahía de Concepción $\left(36^{\circ} \mathrm{S} ; 74^{\circ} \mathrm{W}\right)$. Se recolectaron entre enero y diciembre de 2006 (EN), entre enero y junio de $2007(\mathrm{CN})$ y entre julio y septiembre de 2007 (LN). Todas las muestras fueron extraídas con un ritmo de rotación de 18 días durante las tres condiciones. Se obtuvó un total de 36 muestras: 21 durante $\mathrm{EN}$; 10 durante $\mathrm{CN}$ y 5 durante LN.

El procedimiento utilizado para disminuir el crecimiento bacteriano, regular la salinidad y almacenar las muestras fue el propuesto por Fischer y Wefer (1991) (para más detalles ver Marchant et al. 1998, Gajardo y Marchant 2012). En el laboratorio, la muestra se dividió dos veces con un submuestreador y se utilizó un cuarto del total.

Las conchillas se recogieron de forma individual de cada muestra húmeda utilizando una pipeta Pasteur, y luego se lavaron y secaron a temperatura ambiente. Los foraminíferos se dividieron en tres fracciones de tamaño: $>212,212-150$ y $150-63 \mu \mathrm{m}$. Se utilizaron las fracciones $>150 \mu \mathrm{m}$ para identificar y obtener las frecuencias de las especies encontradas. Los foraminíferos de menor tamaño no se utilizaron dado que podrían inducir a error en su identificación. La clasificación taxonómica se llevó a cabo siguiendo el ordenamiento propuesto por Boltovskoy (1976), Loeblich y Tappan (1988) y Coloma et al. (2005). El flujo de foraminíferos planctónicos se determinó mediante la totalidad de individuos (expresado en ind $\mathrm{m}^{-2} \mathrm{~d}^{-1}$ ). Finalmente, las conchillas fueron pesadas (mg) con el objetivo de determinar el flujo de carbonato de calcio de foraminíferos $\left(\mathrm{mg} \mathrm{m}^{-2} \mathrm{~d}^{-1}\right)$. Ambos parámetros fueron calculados con base en el número de individuos y el peso, respectivamente, multiplicado por dos (tamaño de la malla de recolección en $\mathrm{m}^{2}$ ) y dividido por el número de días de rotación (18 días).

Para determinar los posibles sesgos respecto a la riqueza encontrada durante cada evento, dado que el número de muestras no es homogéneo en las tres condiciones, se realizó un análisis de rarefacción basado en la abundancia mediante el re-muestreo repetido y aleatorio de un conjunto de $N$ individuos (Gotelli y Colwell 2001). Esto fue realizado mediante el programa BioDiversity-Pro v2.

Para determinar la diversidad, se utilizó el índice de Shannon-Wienner (Krebs 1985), mediante el programa PAST v2.10, ya que este índice prioriza tanto la riqueza como la uniformidad de las abundancias de los individuos de cada especie y no la dominancia, sobreestimando a las especies más abundantes y restándole importancia a las especies más 
Gajardo et al.: Planktonic foraminifera as a proxy for oceanographic conditions in the southeastern Pacific

\section{RESULTS}

During 2006, sea surface temperatures $>20^{\circ} \mathrm{C}$ were registered, according to data given by the US National Oceanic and Atmospheric Administration (NOAA), decreasing to a seasonal minimum in July and August, coinciding with the EN event. During January and June 2007, temperatures tended towards resuming the normal levels for Concepción Bay $\left(14-15^{\circ} \mathrm{C}\right)$, and between July and September 2007, they continued to decrease to lower than the records for 2006, coinciding with the LN condition (fig. 1a).

The foraminiferal calcium carbonate flux during EN presented an average of $5.08 \mathrm{mg} \mathrm{m}^{-2} \mathrm{~d}^{-1}$ (standard deviation (SD): 3.18) with two maximum points during the summer months: one during February and March $\left(8 \mathrm{mg} \mathrm{m}^{-2} \mathrm{~d}^{-1}\right)$ and the other during November and December $\left(11 \mathrm{mg} \mathrm{m}^{-2} \mathrm{~d}^{-1}\right)$. During NC in 2007, the observed calcium carbonate flux was lower than during EN with an average of $2.05 \mathrm{mg} \mathrm{m}^{-2} \mathrm{~d}^{-1}$ (SD: 1.48), reaching values lower than $0.5 \mathrm{mg} \mathrm{m}^{-2} \mathrm{~d}^{-1}$ towards the end of the study period. During LN, an average calcium carbonate flux of $2.6 \mathrm{mg} \mathrm{m}^{-2} \mathrm{~d}^{-1}$ (SD: 2.02) was observed with an increase of over $5 \mathrm{mg} \mathrm{m}^{-2} \mathrm{~d}^{-1}$ towards the end of September (fig. 1b).

Regarding species richness, a total of 19 species were found: 18 during $\mathrm{EN}, 14$ during $\mathrm{NC}$, and 14 during $\mathrm{LN}$ (table 1). During EN, the warm period, five species dominated the planktonic foraminiferal composition: $N$. incompta (63\%), G. bulloides (15\%), Globorotalia scitula (8.5\%), $N$. dutertrei (4\%), and $N$. pachyderma $(2.6 \%)$; these species represented $93 \%$ of the total and the other 13 species the remaining 7\%. During $\mathrm{NC}$ the most representative species were $N$. incompta (68\%), Globigerinita glutinata $(9.2 \%), G$. scitula (8.8\%), G. bulloides (6.2\%), and N. dutertrei $(1.8 \%)$; they comprised $85 \%$ of the total abundance and the other nine species the remaining $15 \%$. Finally, during LN, the fauna association was similar to $\mathrm{NC}$ with the presence of N. incompta (76\%), G. glutinata (10\%), G. bulloides $(8.5 \%)$, G. scitula (1.5\%), and Globorotalia truncatulinoides $(\sim 1 \%)$; they represented $97 \%$ of the total and the remaining nine species only $3 \%$. Note the absence of $N$. dutertrei during LN (fig. 1c).

Like calcium carbonate flux, foraminiferal flux during EN showed large variations (an average of 622 ind $\mathrm{m}^{-2} \mathrm{~d}^{-1}$, SD: 456.9), with maximums in February and March, July, and the end of November and December, reaching over 1600 ind $\mathrm{m}^{-2} \mathrm{~d}^{-1}$. On the contrary, during $\mathrm{NC}$, foraminiferal flux descended to 102 ind $\mathrm{m}^{-2} \mathrm{~d}^{-1}$ in February, presented an increasing trend during the following months, and it finally reached a minimum of 2.2 ind $\mathrm{m}^{-2} \mathrm{~d}^{-1}$ in April. During LN, foraminiferal flux maintained an average over 350 ind $\mathrm{m}^{-2} \mathrm{~d}^{-1}$ (SD: 255.7), tending towards an increase at the end of September (fig. 1b).

The diversity analysis determined an average of 1.19 during EN, 1.1 during NC, and 1.01 during LN. This variable escasas. Para establecer las diferencias estadísticas en las variables estudiadas entre cada evento ( $\mathrm{EN}, \mathrm{CN}$ y $\mathrm{LN})$, se realizó un análisis de varianza (ANOVA) una prueba no paramétrica de Kruskal-Wallis según el caso. En ambos casos se utilizó un nivel de significancia 0.05 y $n$-1 grado de libertad con el programa PAST v2.15.

\section{RESULTADOS}

Según datos entregados por la Administración Nacional Oceánica y Atmosférica (NOAA) de los Estados Unidos, durante 2006 se registraron valores de temperatura superficial del mar $>20^{\circ} \mathrm{C}$ que descendieron a un mínimo estacional en julio y agosto, coincidente con el evento EN. Durante enero y junio de 2007, se presentó una tendencia a retomar la temperatura normal registrada para la bahía de Concepción $\left(14-15^{\circ} \mathrm{C}\right)$. Entre julio y septiembre de 2007 se observó una continuidad en la tendencia a la disminución de la temperatura, menor que la registrada durante 2006, coincidente con la condición de LN (fig. 1a).

El flujo de carbonato de calcio de foraminíferos durante EN presentó un promedio de $5.08 \mathrm{mg} \mathrm{m}^{-2} \mathrm{~d}^{-1}$ (desviación estándar (DE): 3.18) con dos puntos máximos: uno durante febrero y marzo $\left(8 \mathrm{mg} \mathrm{m}^{-2} \mathrm{~d}^{-1}\right)$ y otro durante noviembre y diciembre $\left(11 \mathrm{mg} \mathrm{m}^{-2} \mathrm{~d}^{-1}\right)$. Durante $\mathrm{CN}$ en 2007 , se observó un flujo de carbonato de calcio de foraminíferos menor que durante EN, con un promedio de $2.05 \mathrm{mg} \mathrm{m}^{-2} \mathrm{~d}^{-1}$ (DE: 1.48) que llegó a valores por debajo de $0.5 \mathrm{mg} \mathrm{m}^{-2} \mathrm{~d}^{-1}$ al finalizar este período de estudio. Durante el evento LN, se observó un flujo de carbonato de calcio de foraminíferos promedio de $2.6 \mathrm{mg} \mathrm{m}^{-2} \mathrm{~d}^{-1}$ (DE: 2.02) y un aumento por sobre los $5 \mathrm{mg} \mathrm{m}^{-2} \mathrm{~d}^{-1}$ a fines de septiembre (fig. 1b).

En relación con la riqueza de especies, se encontró un total de 19 especies: 18 durante EN, 14 durante $\mathrm{CN}$ y 14 durante LN (tabla 1). En este contexto, la composición de foraminíferos planctónicos durante $\mathrm{EN}$ (periodo cálido) estuvo representada por cinco especies dominantes: $N$. incompta (63\%), G. bulloides (15\%), Globorotalia scitula (8.5\%), N. dutertrei (4\%), N. pachyderma (2.6\%); estás especies representaron el $93 \%$ del total y las otras trece especies representaron el 7\% restante. Durante $\mathrm{CN}$, la asociación faunística estuvo representada por $N$. incompta $(68 \%)$, Globigerinita glutinata $(9.2 \%)$, G. scitula $(8.8 \%)$, G. bulloides $(6.2 \%)$ y $N$. dutertrei ( $1.8 \%)$; estas especies representaron el $85 \%$ de la abundancia total y las nueve especies restantes conformaron el 15\% restante. Durante LN, la asociación faunística fue similar a la que se presentó durante $\mathrm{CN}$, observándose $N$. incompta (76\%), G. glutinata (10\%), G. bulloides (8.5\%), G. scitula (1.5\%) y Globorotalia truncatulinoides $(\sim 1 \%)$; éstas conformaron el $97 \%$ del total y las nueve especies restantes conformaron sólo un 3\%. Se destaca la ausencia de $N$. dutertrei durante LN (fig. 1c).

Al igual que el flujo de carbonato de calcio de foraminíferos, el flujo de individuos fluctuó durante EN (promedio de 

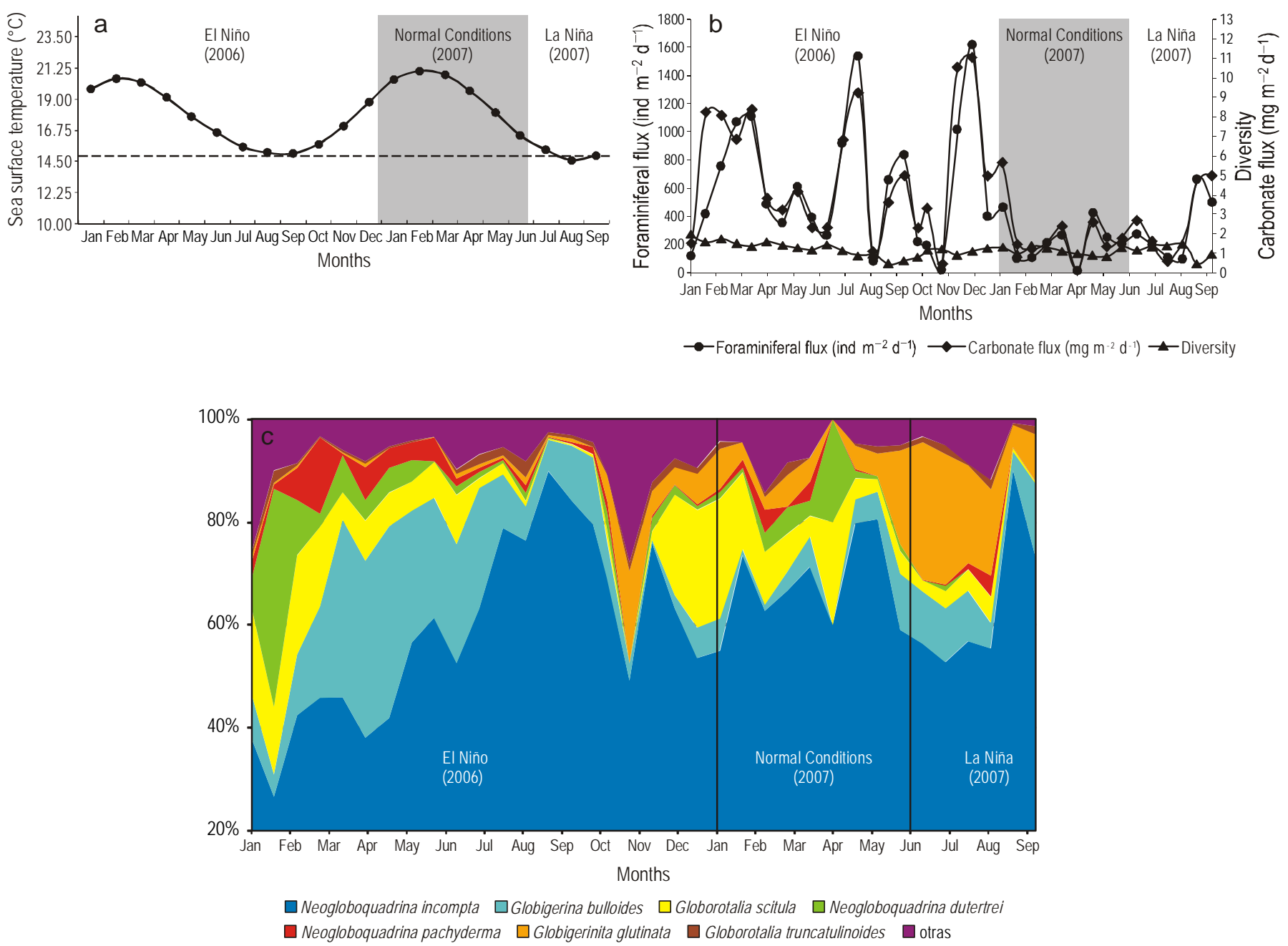

Figure 1. (a) Sea surface temperature during 2006 and 2007 (http://www.esrl.noaa.gov/psd/data/gridded/data.noaa.oisst.v2.html) off Concepción, Chile $\left(36^{\circ} \mathrm{S}\right)$, and mean surface temperature (dashed line). (b) Foraminiferal flux, calcium carbonate flux, and diversity during the different conditions: El Niño, January to December 2006; normal conditions, January to June 2007; and La Niña, July to September 2007. (c) Relative species abundance.

Figura 1. (a) Temperatura superficial del mar durante 2006 y 2007 (http://www.esrl.noaa.gov/psd/data/gridded/data.noaa.oisst.v2.html) frente a Concepción $\left(36^{\circ} \mathrm{S}\right)$, y temperatura superficial promedio (línea discontinua). (b) Flujo de foraminíferos, carbonato de calcio y diversidad durante las distintas condiciones: El Niño, enero a diciembre de 2006; condiciones normales, enero a junio de 2007; La Niña, julio a septiembre de 2007. (c) Abundancia relativa de las especies.

thus remained approximately constant, with a slight tendency to decrease during LN and decreasing in September (fig. 1b).

For the calcium carbonate flux the Kruskal-Wallis test showed significant differences $(P<0.05, P=0.02)$, specifically between the EN event and $\mathrm{NC}(P=0.008)$, with a lower flux during $\mathrm{NC}$; however, there were no significant differences between EN and LN $(P=0.17)$ or between NC and LN $(P=1)$. Foraminiferal flux showed significant differences between $\mathrm{EN}$ and $\mathrm{NC}(P=0.016)$ with a lower flux during NC. For diversity, $P=0.7$, that is, diversity between $\mathrm{EN}, \mathrm{NC}$, and $\mathrm{LN}$ was not statistically different. A rarefaction analysis carried out to compare the different periods evidenced a lack of samples during $\mathrm{NC}$ and $\mathrm{LN}$, as the curve is not asymptotic; if so, the maximum expected richness would be found
622 ind $\mathrm{m}^{-2} \mathrm{~d}^{-1}$, DE: 456.9), presentando máximos en febrero-marzo, julio y a fines de noviembre y diciembre, llegando a más de 1600 ind $\mathrm{m}^{-2} \mathrm{~d}^{-1}$. Por el contrario, durante $\mathrm{CN}$, el flujo de foraminíferos descendió a los 102 ind $\mathrm{m}^{-2} \mathrm{~d}^{-1}$ en febrero, tendió a incrementar en los meses posteriores y finalmente alcanzó un mínimo no superior a 2.2 ind $\mathrm{m}^{-2} \mathrm{~d}^{-1}$ en abril. Durante LN, el flujo de individuos se mantuvo en promedio por arriba de los 350 ind $\mathrm{m}^{-2} \mathrm{~d}^{-1}$ (DE: 255.7), tendiendo a aumentar hacia finales de septiembre (fig. 1b).

El análisis de diversidad determinó un promedio de 1.19 durante EN, 1.1 durante CN y 1.01 durante LN. Por tanto, esta variable se mantuvo aproximadamente constante, con una leve tendencia a disminuir durante LN y con un decrecimiento en septiembre (fig. 1b). 
Table 1. Species present (+) or absent (-) during El Niño (2006), normal conditions (2007) and La Niña (2007).

Tabla 1. Especies presentes (+) o ausentes (-) durante El Niño (2006), condiciones normales (2007) y La Niña (2007).

\begin{tabular}{|c|c|c|c|}
\hline Species & El Niño & $\begin{array}{c}\text { Normal } \\
\text { conditions }\end{array}$ & La Niña \\
\hline Globigerina bulloides & + & + & + \\
\hline Globigerinella calida & + & - & - \\
\hline Globigerinita glutinata & + & + & + \\
\hline Globigerinoides ruber & + & - & - \\
\hline Globorotalia crassaformis & + & + & + \\
\hline Globorotalia inflata & + & + & + \\
\hline Globorotalia menardi & + & - & - \\
\hline Globorotalia scitula & + & + & + \\
\hline Globorotalia truncatulinoides & + & + & + \\
\hline Globorotaloides hexagonus & + & + & + \\
\hline Hastigerina pelagica & + & + & + \\
\hline Neogloboquadrina dutertrei & + & + & + \\
\hline Neogloboquadrina incompta & + & + & + \\
\hline Neogloboquadrina pachyderma & + & + & + \\
\hline Orbulina universa & + & + & + \\
\hline Pulleniatina obliquiloculata & + & - & - \\
\hline Turborotalita humilis & + & - & - \\
\hline Turborotalita quinqueloba & + & + & + \\
\hline Globigerinoides sacculifer & - & + & + \\
\hline Total species & 18 & 14 & 14 \\
\hline
\end{tabular}

independent of individual abundance, as occurred during EN (fig. 2a). Subsequently, so as to statistically verify these results, we carried out an ANOVA with the expected richness data for each condition (EN, NC, and LN) for 500 individuals. This value was selected arbitrarily given that there are data for all three conditions reaching 3500 individuals (table $2)$. This analysis showed $P<0.05(P=0.004)$, indicating significant differences between the expected richness during EN, NC, and LN. Using an a posteriori Tukey test we verified that these differences were found mainly between $\mathrm{LN}$ and $\mathrm{EN}(P=0.03)$ and between $\mathrm{LN}$ and $\mathrm{NC}(P=0.003)$ (fig. 2b).

\section{DISCUSSION}

ENSO macroclimate conditions can be determined at a global level, so at a local level the climate anomalies registered in the study area were used to establish the events that occurred during the study period. We found lower species richness (18) during the warm period studied (January to December 2006) compared to the 19 species documented off the coast of Coquimbo $\left(30^{\circ} \mathrm{S}\right)$ during the 1991-1992 EN
Según la prueba de Kruskal-Wallis, existieron diferencias significativas $(P<0.05, P=0.02)$ en el flujo de carbonato de calcio entre eventos, específicamente entre el evento EN y $\mathrm{CN}(P=0.008)$, presentándose un menor flujo durante $\mathrm{CN}$; sin embargo, no hubo diferencias significativas $(P=0.17)$ entre EN y LN ni entre CN y LN $(P=1)$. El flujo de foraminíferos mostró diferencias significativas entre el evento EN y $\mathrm{CN}(P=0.016)$, con un menor flujo durante $\mathrm{CN}$. La diversidad entre EN, CN y LN no fue estadísticamente diferente $(P=0.7)$. El análisis de rarefacción evidenció una falta de muestreo durante $\mathrm{CN}$ y LN, ya que la curva no fue asintótica; si fue así, se alcanzaría el máximo de riqueza esperada independientemente de la abundancia de los individuos, como sucedió durante EN (fig. 2a). Posteriormente, con el objeto
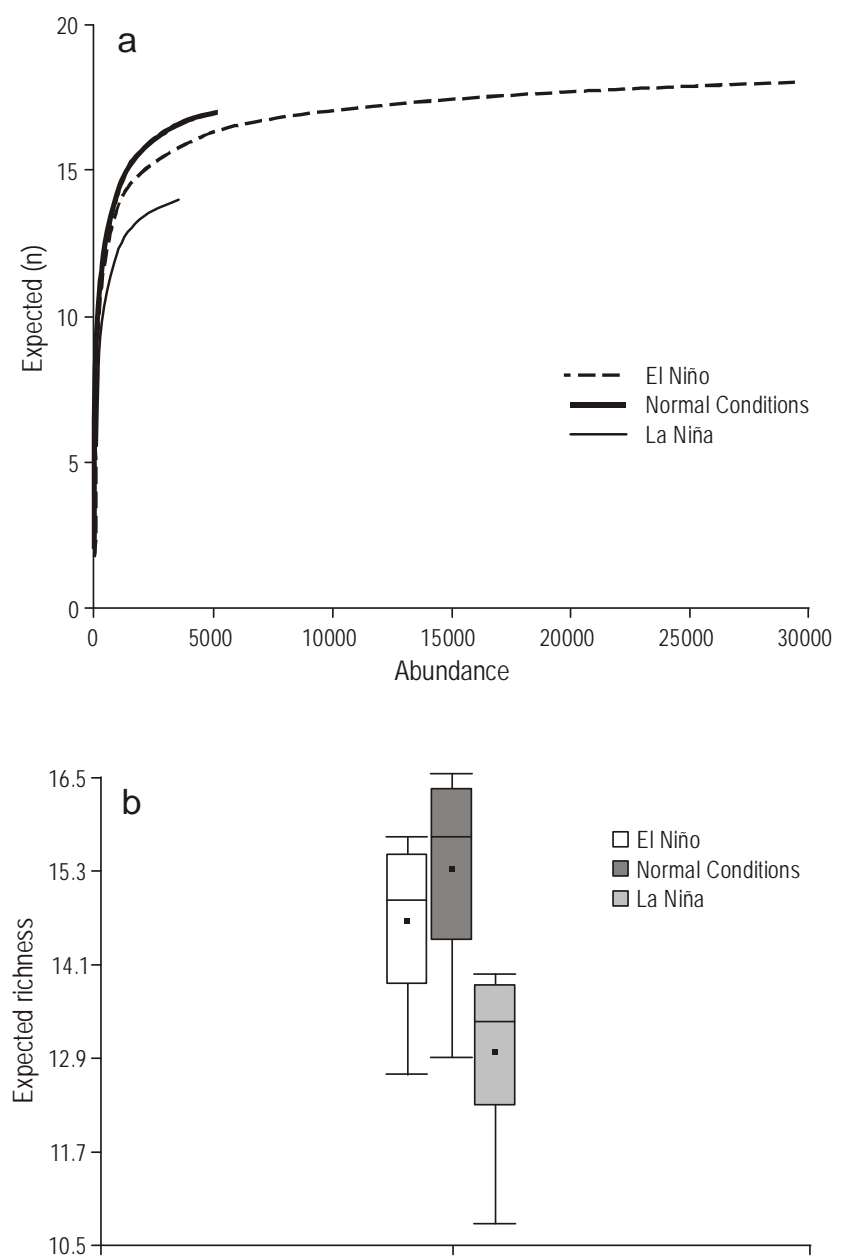

Figure 2. (a) Rarefaction curves for El Niño (EN), normal conditions (NC), and La Niña (LN). (b) Box plots representing the expected richness for each oceanographic condition (EN 2006, NC 2007, LN 2007) off Concepción.

Figura 2. (a) Curvas de rarefacción para El Niño (EN), condiciones normales $(\mathrm{CN})$ y La Niña (LN). (b) Diagramas de caja que representan la riqueza esperada para cada condición oceanográfica (EN 2006, CN 2007, LN 2007) frente a Concepción. 
Table 2. Expected richness for the three oceanographic conditions given the abundance.

Tabla 2. Riqueza esperada en las tres condiciones oceanográficas evaluadas dada la abundancia.

\begin{tabular}{cccc}
\hline Abundance & El Niño & Normal conditions & La Niña \\
\hline 500 & 12.70 & 12.90 & 10.78 \\
1000 & 13.85 & 14.41 & 12.27 \\
1500 & 14.48 & 15.23 & 12.95 \\
2000 & 14.92 & 15.75 & 13.35 \\
2500 & 15.25 & 16.10 & 13.62 \\
3000 & 15.52 & 16.36 & 13.83 \\
3500 & 15.74 & 16.56 & 13.99 \\
\hline
\end{tabular}

(Marchant et al. 1998) and the 26 species recorded during the 1997-1998 EN (Coloma et al. 2005), which would correspond directly to the intensity of each event. On the other hand, the rarefaction analysis indicated a low number of samples available for finding maximum richness during $\mathrm{NC}$ and $\mathrm{LN}$, but note that whereas sampling was conducted over the entire period under $\mathrm{NC}$, during $\mathrm{LN}$ samples were only collected from July to September 2007 and, according to NOAA data, this event extended until May 2008. This predictive analysis suggests that richness should be greater than registered in this study (14); however, during NC, the documented richness (14) was lower than the 17 species found by Marchant et al. (1998) during NC in 1993 and 1994.

Average foraminiferal calcium carbonate flux was greater during EN than during LN; however, during the last sampling months this flux increased considerably, coinciding with the temporal proximity to the maximum intensity of this event, which according to values obtained from the NOAA database (Oceanic Niño Index, January-February: -1.4) occurred between January and February 2008. Even so, the calcium carbonate flux detected off Concepción Bay $\left(36^{\circ} \mathrm{S}\right)$ was much lower than the levels registered by Marchant et al. (2004) off Coquimbo $\left(30^{\circ} \mathrm{S}\right.$ ) (with a maximum $>100 \mathrm{mg} \mathrm{m}^{-2}$ $\mathrm{d}^{-1}$ ). Also, during $\mathrm{NC}$, calcium carbonate flux was lower at a greater latitude ( $2.05 \mathrm{mg} \mathrm{m}^{-2} \mathrm{~d}^{-1}$, on average) than at a lower altitude ( $\sim 90 \mathrm{mg} \mathrm{m}^{-2} \mathrm{~d}^{-1}$, on average) (Marchant et al. 1998). This shows a latitudinal variability indicating changes in productivity (e.g., Thomas et al. 2001), which are caused by nutrient availability and chlorophyll concentration, given that these organisms greatly depend on the eutrophic layers (Bé and Hutson 1977).

The fauna association detected is typical of subantarctic waters under $\mathrm{NC}$ with species such as $N$. incompta, G. bulloides, and G. glutinata, the first one being the most abundant during all three evaluated conditions. This would respond to the presence of cold waters from the HCS (Boltovskoy 1976). During EN, the species N. incompta, G. bulloides, G. scitula, N. dutertrei, and N. pachyderma composed the fauna association, and both cold-water species de evidenciar dichos resultados estadísticamente, se realizó una ANOVA con los datos de riqueza esperada para cada condición (EN, CN y LN) para 500 individuos. Este valor fue tomado arbitrariamente dado que se tienen datos de hasta 3500 individuos para las tres condiciones (tabla 2). Este análisis mostró $P<0.05(P=0.004)$, indicando diferencias significativas entre las riquezas esperadas de EN, CN y LN. Con una prueba a posteriori de Tukey se verificó que estas diferencias se encontraron principalmente entre LN y EN $(P=0.03)$ y entre $\mathrm{LN}$ y CN $(P=0.003)$ (fig. $2 b)$.

\section{DISCUSIÓN}

Las condiciones macroclimáticas ENSO pueden determinarse a nivel global, por lo que a nivel local fue necesario recurrir a las anomalías térmicas registradas en el área de estudio para establecer los eventos acontecidos durante el período de estudio. Se encontró una riqueza menor (18) durante la fase cálida estudiada (enero a diciembre de 2006) en comparación con las 19 especies documentadas frente a las costas de Coquimbo ( $30^{\circ} \mathrm{S}$ ) durante EN de 1991-1992 (Marchant et al. 1998) y las 26 especies registradas durante EN de 1997-1998 (Coloma et al. 2005), lo que respondería directamente a la intensidad de cada evento. Por otro lado, el análisis de rarefacción, indicó un bajo número de muestras disponibles para encontrar una máxima riqueza durante $\mathrm{CN}$ y LN; pero, es importante mencionar que se muestreó todo el período durante $\mathrm{CN}$, mientras que durante $\mathrm{LN}$ las muestras se recolectaron de julio a septiembre de 2007 y, según la NOAA, este evento se extendería hasta mayo de 2008. Este análisis predictivo sugiere que debería haber una mayor riqueza que la registrada en este estudio (14); sin embargo, durante las $\mathrm{CN}$ se documenta una riqueza menor (14) que las 17 especies registradas por Marchant et al. (1998) durante las CN de 1993 y 1994.

El flujo promedio de carbonato de calcio de foraminíferos fue mayor durante EN que durante LN; sin embargo, durante los últimos meses de muestreo este flujo aumentó considerablemente, lo que sería concordante con el acercamiento temporal al máximo de intensidad de este evento, el cual ocurrió en enero y febrero de 2008 sensu valores obtenidos de la base de datos de la NOAA (NOI (Oceanic Niño Index) enerofebrero: -1.4). Aun así, este flujo de carbonato de calcio de foraminíferos detectado frente a la bahía Concepción $\left(36^{\circ} \mathrm{S}\right)$ es mucho menor que el registrado por Marchant et al. (2004) frente a Coquimbo $\left(30^{\circ} \mathrm{S}\right)$ (con un máximo $\left.>100 \mathrm{mg} \mathrm{m}^{-2} \mathrm{~d}^{-1}\right)$. Así mismo, durante $\mathrm{CN}$, el flujo de carbonato de calcio fue menor a una mayor latitud (2.05 $\mathrm{mg} \mathrm{m}^{-2} \mathrm{~d}^{-1}$, en promedio) que a una menor latitud ( $\sim 90 \mathrm{mg} \mathrm{m}^{-2} \mathrm{~d}^{-1}$, en promedio) (Marchant et al. 1998). Se observó una variabilidad a nivel latitudinal que indica cambios en la productividad (e.g., Thomas et al. 2001), que son causados por la disponibilidad de nutrientes y la concentración de clorofila, ya que estos organismos tienen una gran dependencia de las capas eutróficas (Bé y Hutson 1977). 
Gajardo et al.: Planktonic foraminifera as a proxy for oceanographic conditions in the southeastern Pacific

(present during NC) and warm-water species (e.g., G. scitula) were recorded; G. scitula is typical of warm temperate to intermediate subtropical areas (Boltovskoy 1981). The abundance of $N$. dutertrei changes as the oceanographic conditions vary: it is abundant when sea temperature increases (EN), less abundant during $\mathrm{NC}$, and even less abundant during LN; this reaffirms the EN condition during the January-December 2006 period since this species is considered an indicator of this event (Marchant et al. 1998). Furthermore, Giglio (2001) documented the disappearance of $N$. dutertrei under NC and during the 1995-1996 LN event, coinciding with the results presented in this study. This species can thus be useful in studies focused on detecting current and past oceanographic changes.

The most representative species during LN were the same as during $\mathrm{NC}$ but the proportions differed, as is the case of G. scitula flux that decreased from $>200$ to $<23$ ind $\mathrm{m}^{-2} \mathrm{~d}^{-1}$ from $\mathrm{NC}$ to $\mathrm{LN}$. The $\mathrm{EN}$ indicator species $N$. dutertrei disappeared and G. truncatulinoides appeared as part of the association, presenting great tolerance to temperature changes (Boltovskoy 1981).

The foraminiferal flux detected in this study was greater during EN (622 ind $\mathrm{m}^{-2} \mathrm{~d}^{-1}$ ), reaching a maximum of 1600 ind $\mathrm{m}^{-2} \mathrm{~d}^{-1}$ in November and December 2006 (summer season), which would preliminarily indicate the presence of upwelling during this period. The abundance registered in this study is low in relation to the findings for Coquimbo during the 1991-1992 EN event when the foraminiferal flux reached 3000 ind $\mathrm{m}^{-2} \mathrm{~d}^{-1}$ (Marchant et al. 1998); this indicates that the 1991-1992 EN event was more intense than the 2006 EN event, which is corroborated by the Southern Oscillation Index values given by the NOAA. The lowest foraminiferal flux for the three evaluated conditions was registered under $\mathrm{NC}$, on average 230 ind $\mathrm{m}^{-2} \mathrm{~d}^{-1}$, which is lower than the flux documented at $30^{\circ} \mathrm{S}$ during 1994 by Marchant et al. (1998) where 4000 ind $\mathrm{m}^{-2} \mathrm{~d}^{-1}$ were recorded with a maximum of 17,500 ind $\mathrm{m}^{-2} \mathrm{~d}^{-1}$. This high variability in foraminiferal flux, as well as in calcium carbonate flux, would respond to the changes in productivity indicating the presence of coastal upwelling. During the LN event, foraminiferal flux was lower ( 350 ind $\left.\mathrm{m}^{-2} \mathrm{~d}^{-1}\right)$ than that registered during the 1995-1996 LN event (9300 ind $\mathrm{m}^{-2} \mathrm{~d}^{-1}$ ) (Marchant et al. 2004). Furthermore, the statistical analysis showed significant differences in foraminiferal flux between the studied conditions, specifically between EN and NC, which reaffirms the idea that conditions during $\mathrm{LN}$ are similar to those during NC.

Under EN conditions an increase was observed in the flux of the upwelling indicator species during the summer period (i.e., December to January). During LN, upwelling events should be more frequent; however, in this study the upwelling indicator species (e.g., G. bulloides) occurred with a low specimen flux during this event, not coinciding with the results documented by Watkins et al. (1998) for the tropical equatorial zone $\left(8^{\circ} \mathrm{N}-11^{\circ} \mathrm{S}\right)$, where the increase in $G$.
La asociación faunística ( $N$. incompta, G. bulloides y G. glutinata) es propia de aguas subantárticas durante $\mathrm{CN}$. La gran abundancia de $N$. incompta durante las tres condiciones oceanográficas corresponden con la presencia de aguas frías del SCH (Boltovskoy 1976). Durante EN, las especies $N$. incompta, G. bulloides, G. scitula, $N$. dutertrei y $N$. pachyderma conformaron la asociación faunística, y fue posible registrar una mezcla de especies tanto aguas frías (que están en $\mathrm{CN}$ ) como de aguas cálidas (e.g., G. scitula); G. scitula es una especie típica de zona templada-cálida a subtropical intermedia (Boltovskoy 1981). La abundancia de $N$. dutertrei cambia a medida que varían las condiciones oceanográficas: es abundante cuando hay un aumento en la temperatura del mar (EN), desciende su abundancia durante $\mathrm{CN}$ y es aún menos abundante durante LN; esto reafirma la condición de EN durante el período enero-diciembre de 2006 debido a que esta especie es tipificada como indicadora del evento (Marchant et al. 1998). Además, Giglio (2001) documentó la desaparición $N$. dutertrei durante $\mathrm{CN}$ y durante $\mathrm{LN}$ 1995-1996, coincidiendo con lo expuesto en este estudio. Esta especie puede ser de mucha ayuda en estudios enfocados a detectar cambios oceanográficos tanto actuales como pasados.

Las especies más representativas durante LN fueron las mismas que durante $\mathrm{CN}$ pero las proporciones difirieron, como sucedió con el flujo de G. scitula, que disminuyó de $>200$ a $<23$ ind $\mathrm{m}^{-2} \mathrm{~d}^{-1}$ de $\mathrm{CN}$ a $\mathrm{LN}$. La especie indicadora del evento EN (N. dutertrei) desapareció, y G. truncatulinoides apareció como parte de la asociación, presentando una gran tolerancia a los cambios de temperatura (Boltovskoy 1981).

El flujo de individuos detectado en este estudio fue mayor durante $\mathrm{EN}$ (622 ind $\mathrm{m}^{-2} \mathrm{~d}^{-1}$ ), alcanzando un máximo de 1600 ind $\mathrm{m}^{-2} \mathrm{~d}^{-1}$ durante noviembre y diciembre de 2006 (época estival), lo que indicaría, preliminarmente, la presencia de surgencias durante este período. La abundancia registrada en este estudio es baja en relación con lo encontrado para Coquimbo durante EN de 1991-1992, cuando el flujo de foraminíferos planctónicos alcanzó 3000 ind $\mathrm{m}^{-2} \mathrm{~d}^{-1}$ (Marchant et al. 1998); esto sugiere que el evento EN de 1991-1992 fue más intenso que el evento EN de 2006, lo que es corroborado por los valores del Índice de Oscilación del Pacífico Sur (SOI) dado por la NOAA. Durante CN, se registró el flujo promedio de individuos más bajo (230 ind $\left.\mathrm{m}^{-2} \mathrm{~d}^{-1}\right)$ de las tres condiciones evaluadas, que es menor que el documentado a los $30^{\circ} \mathrm{S}$ durante 1994 por Marchant et al. (1998), donde se documentaron 4000 ind $\mathrm{m}^{-2} \mathrm{~d}^{-1}$ con un máximo de 17,500 ind $\mathrm{m}^{-2} \mathrm{~d}^{-1}$. Esta alta variabilidad en el flujo de individuos, al igual que el flujo de carbonato de calcio de foraminíferos, respondería a los cambios en la productividad, que indicarían la presencia de afloramientos costeros. Durante el evento LN, el flujo de foraminíferos fue menor (350 ind $\mathrm{m}^{-2} \mathrm{~d}^{-1}$ ) que el registrado durante $\mathrm{LN}$ de 1995-1996 (9300 ind $\mathrm{m}^{-2} \mathrm{~d}^{-1}$ ) (Marchant et al. 2004). Además, el análisis estadístico reveló diferencias significativas 
bulloides was the greatest faunal exchange characterizing the event.

Seasonality is an important factor when analyzing these results, specifically during conditions that do not last an entire year to allow contrasting between seasons, as occurs with NC and LN. Information about seasonality off Coquimbo is available (Marchant et al. 1998).

\section{Conclusions}

A comparative analysis of $\mathrm{NC}, \mathrm{LN}$, and $\mathrm{EN}$ conditions through planktonic foraminifera sedimentation revealed a fauna association typical of subantarctic waters during $\mathrm{NC}$ and LN given the presence of cold waters. The same was not observed for EN during which a mixture of cold- and warm-water species occurred responding to the temperature increase generated during that event. A low biodiversity was registered: 18 species during EN, 14 species during $\mathrm{NC}$, and 14 species during LN. The low diversity during LN cannot be confirmed because of the lack of samples to complete the period in which the event occurred. Of the measured parameters - calcium carbonate flux, foraminiferal flux, and diversity - only the latter presented no significant differences between the three evaluated conditions and remained approximately constant during the entire sampling period. The significant differences in calcium carbonate flux and foraminiferal flux were found specifically between $\mathrm{NC}$ and EN, with higher values during the latter event.

\section{ACKNOWLEDGMENTS}

Funding to obtain samples was obtained from the following: FONDECYT projects 1010912 and 1040968, SCOR (Scientific Committee on Oceanic Research) Working Group 138 membership, and FONDAP-COPAS project 15010007. Financial support was also provided by the Austral University of Chile (Dirección de Investigación y Desarrollo). The authors thank the officers and crew of the research vessels Abate Molina and Vidal Gormaz, as well as Concepción University for allowing the use of their infrastructure.

\section{REFERENCES}

Aceituno P, Montecinos A. 1993. Análisis de la estabilidad de la relación entre la Oscilación del Sur y la precipitación en América del Sur. Bull. Inst. Français Etud. Andines 22: 53-64.

Bé AWH, Hutson WH. 1977. Ecology of planktonic foraminifera and biogeographic patterns of life and fossil assemblages in the Indian Ocean. Micropaleontology 23: 369-414. http://dx.doi.org/10.2307/1485406

Bello M, Barbieri MA, Salinas S, Soto L. 2004. Surgencia costera en la zona central de Chile, durante el ciclo El Niño-La Niña 1997-1999. In: Avaria S, Carrasco J, Rutllant J, Yáñez E (eds.), El Niño-La Niña 1997-2000. Sus Efectos en Chile. CONA, Chile, Valparaíso, pp. 77-94.

Berger WH, Smetacek VS, Wefer G. 1989. Ocean productivity and paleoproductivity - an overview. In: Berger WH, Smetacek VS, respecto al flujo de foraminíferos entre las condiciones estudiadas, específicamente durante $\mathrm{EN}$ y $\mathrm{CN}$, reafirmando que las condiciones que se generan durante LN son similares a las $\mathrm{CN}$.

Durante EN, se observó un aumento en el flujo de las especies indicadoras de surgencias durante el período estival (i.e., de diciembre a enero). Durante LN, las surgencias serían más frecuentes; sin embargo, en este estudio las especies indicadoras de surgencias (e.g., G. bulloides) se presentaron con un bajo flujo de individuos durante este evento, siendo esto inconsistente con lo documentado por Watkins et al. (1998) para la zona ecuatorial tropical $\left(8^{\circ} \mathrm{N}-11^{\circ} \mathrm{S}\right)$, donde el aumento de G. bulloides fue el mayor recambio faunístico que caracterizaría este evento.

La estacionalidad es un factor importante al momento del análisis de estos resultados, específicamente durante las condiciones en donde no se tiene un año completo de datos que permita el contraste entre estaciones, como sucedió con $\mathrm{CN} \mathrm{y}$ LN. Sin embargo, se tiene información de la estacionalidad frente a Coquimbo (Marchant et al. 1998).

\section{CONCLUSIONES}

El análisis comparativo de las condiciones oceanográficas EN, CN y LN mediante la sedimentación de foraminíferos planctónicos permitió determinar una asociación faunística típica de aguas subantárticas durante $\mathrm{CN}$ y $\mathrm{LN}$ debido a la presencia de aguas frías. Esto no se observó durante EN, cuando se presentó una mezcla de especies de aguas frías y cálidas, respondiendo al incremento de la temperatura. Se registró una baja diversidad: 18 especies durante EN, 14 durante $\mathrm{CN}$ y 14 durante LN. Para este último evento no es posible afirmar una baja diversidad debido a la falta de muestreo que complete el período en el cual se desarrolla este evento. De los parámetros medidos, (flujo de carbonato de calcio, flujo de foraminíferos y diversidad), sólo la diversidad no presentó diferencias significativas entre las tres condiciones evaluadas, manteniéndose aproximadamente constante durante todo el tiempo de muestreo. Las diferencias significativas del flujo de carbonato de calcio y flujo de foraminíferos se encontraron específicamente entre las $\mathrm{CN}$ y $\mathrm{EN}$, con valores más altos durante este último evento.

\section{Agradecimientos}

El financiamiento para la obtención de las muestras fue adquirido por medio de los siguientes: FONDECYT, proyectos 1010912 y 1040968; SCOR (Scientific Committee on Oceanic Research) Working Group 138 membership; y FONDAP-COPAS, proyecto 15010007 . También se recibió apoyo financiero de la Dirección de Investigación y Desarrollo de la Universidad Austral de Chile. Se agradece a los oficiales y a las tripulaciones de los barcos de investigación Abate Molina y Vidal Gormaz, y a la Universidad de Concepción por permitir el uso de su infraestructura. 
Gajardo et al.: Planktonic foraminifera as a proxy for oceanographic conditions in the southeastern Pacific

Wefer G (eds.), Productivity of the Ocean: Present and Past. Dahlem Workshop Report, Wiley, New York, pp. 1-34.

Boltovskoy E. 1965. Los Foraminíferos Recientes (Biología, Métodos de Estudio, Aplicación Oceanográfica). Editorial Universitaria, Buenos Aires, 510 pp.

Boltovskoy E. 1976. Distribution of recent foraminifera of the South American region In: Heddley RH, Adams C (eds.), Foraminifera. Academia Press, New York, pp. 171-236.

Boltovskoy E. 1981. Foraminifera. In: Boltovskoy D (ed.), Atlas del Zooplancton del Atlántico Sudoccidental y Métodos de Trabajo con el Zooplancton Marino. Publicación Especial del Instituto Nacional de Investigación y Desarrollo Pesquero (INIDEP), Mar del Plata, Argentina, pp. 317-352.

Brandhorst W. 1963. Descripción de las condiciones oceanográficas en las aguas costeras entre Valparaíso y el golfo de Arauco, con especial referencia al contenido de oxígeno y su relación con la pesca (resultados de la expedición AGRIMAR). Ministerio de Agricultura, Dirección de Agricultura y Pesca, Santiago, Chile, $55 \mathrm{pp}$.

Cáceres M. 1992. Vórtices y filamentos observados en imágenes de satélite frente al área de surgencia de Talcahuano, Chile central (33-38.5 ${ }^{\circ}$ S). Invest. Pesq. 37: 55-66.

Cantillanez M, Avendaño M, Thouzeau G, Le Pennec M. 2005. Reproductive cycle of Argopecten purpuratus (Bivalvia: Pectinidae) in La Rinconada marine reserve (Antofagasta, Chile): Response to environmental effects of El Niño and La Niña. Aquaculture 246: 181-195. http://dx.doi.org/10.1016/j.aquaculture.2004.12.031

Carr ME, Kearns E. 2003. Production regimes in four Eastern Boundary Current Systems. Deep-Sea Res. (II) 50: 3199-3221. http://dx.doi.org/10.1016/j.dsr2.2003.07.015

Coloma C, Marchant M, Hebbeln D. 2005. Foraminíferos planctónicos durante El Niño 1997-98 del área de Coquimbo $\left(30^{\circ} \mathrm{S} ; 73^{\circ} \mathrm{W}\right)$, Chile. Gayana 69: 48-77.

Cullen JL, Prell WL. 1984. Planktonic foraminifera of the northen Indian Ocean: Distribution and preservation in surface sediments. Mar. Micropaleontol. 9:1-52 http://dx.doi.org/10.1016/0377-8398(84)90022-7

Daneri G, Dellarossa V, Quiñones R, Jacob B, Montero P, Ulloa O. 2000. Primary production and community respiration in the Humboldt Current System off Chile and associated oceanic areas. Mar. Ecol. Prog. Ser. 197: 41-49. http://dx.doi.org/10.3354/meps197041

Emiliani C. 1955. Pleistocene temperatures. J. Geol. 63: 538-578. http://dx.doi.org/10.1086/626295

Escribano R, Daneri G, Farías L, Gallardo VA, González HE, Gutiérrez D, Lange CB, Morales CE, Pizarro O, Ulloa O, Braun M. 2004. Biological and chemical consequences of the 1997-1998 El Niño in the Chilean coastal upwelling system: A synthesis. Deep-Sea Res. (II) 51: 2389-2411. http://dx.doi.org/10.1016/j.dsr2.2004.08.011

Fernández G, O'Hara PD, Lank DB. 2004. Tropical and subtropical Western Sandpipers (Calidris mauri) differ in life history strategies. Ornitol. Neotrop. 15: 385-394.

Fischer G, Wefer G. 1991. Sampling, preparation and analysis of marine particulate matter. In: Hurd DC, Spencer DW (eds.), The Analysis and Characterization of Marine Particles. Geophys. Monogr. 63: 391-397.

Gajardo N, Marchant M. 2012. Variaciones estacionales de los foraminíferos planctónicos durante 2005-2006 frente a Iquique $\left(20^{\circ} \mathrm{S}\right)$ y Concepción $\left(36^{\circ} \mathrm{S}\right)$, Chile. Latin Am. J. Aquat. Res. 42: $376-388$. http://dx.doi.org/10.3856/vol40-issue2-fulltext-12

Giglio S. 2001. Variación estacional e interanual de la composición isotópica de los foraminíferos planctónicos: Globigerina bulloides y Neogloboquadrina pachyderma (dextral) y su relación con los procesos de surgencia frente a Coquimbo, Chile. BSc dissertation, Escuela de Ciencias del Mar, Facultad de Recursos Naturales, Universidad Católica de Valparaíso, Chile, 66 pp.

González H, Daneri G, Figueroa D, Iriarte J, Lefevre N, Pizarro G, Quiñones R, Sobarzo M, Troncoso A. 1998. Producción primaria y su destino en la trama trófica pelágica y océano profundo e intercambio océano-atmósfera de $\mathrm{CO}_{2}$ en la zona norte de la Corriente de Humboldt $\left(23^{\circ} \mathrm{S}\right)$ : Posibles efectos del evento El Niño 1997-98 en Chile. Rev. Chilena Hist. Nat. 71: 429-458.

Gotelli NJ, Colwell RK. 2001. Quantifying biodiversity: Procedures and pitfalls in the measurement and comparison of species richness. Ecol. Lett. 4: 379-391. http://dx.doi.org/10.1046/j.1461-0248.2001.00230.x

Hebbeln D, Marchant M, Wefer G. 2000. Seasonal variations of the particle flux in the Peru-Chile current at $30^{\circ} \mathrm{S}$ under "normal" and El Niño conditions. Deep-Sea Res. (II) 47: 2101-2128. http://dx.doi.org/10.1016/S0967-0645(00)00018-7

Hormazabal S, Shaffer G, Letelier J, Ulloa O. 2001. Local and remote forcing of sea surface temperature in the coastal upwelling system off Chile. J. Geophys. Res. 106: 16657-16672. http://dx.doi.org/10.1029/2001JC900008

Kelly R, Blanco J. 1984. Proceso de surgencia en Punta Nugurue, Chile (lat. $36^{\circ} \mathrm{S}$ ), marzo 1983. Invest. Pesq. 31: 89-94.

Krebs CJ. 1985. Ecología, Estudio de la Distribución y la Abundancia. Editorial Harla, México, 753 pp.

Loeblich A, Tappan H. 1988. Foraminiferal Genera and Their Classification. Van Nostrand Reinhold, New York, 970 pp.

Marchant M, Hebbeln D, Wefer G. 1998. Seasonal flux patterns of planktic foraminifera in the Peru-Chile Current. Deep-Sea Res. (I) 45: 1161-1185.

Marchant M, Hebbeln D, Giglio S, Coloma C, González HE. 2004. Seasonal and interanual variability in the flux of planktic foraminifers in the southern Humboldt Current System off central Chile. Deep-Sea Res. (II) 51: 2441-2455. http://dx.doi.org/10.1016/j.dsr2.2004.08.013

McLean JD, De Freitas CR, Carter RM. 2009. Influence of the Southern Oscillation on tropospheric temperature. J. Geophys. Res. 114 (D14104): 1-8.

Ramage C. 1986. El Niño. Invest. Cienc. 119: 40-48.

Rasmusson EM, Carpenter TH. 1982. Variations in tropical sea surface temperature and surface wind fields associated with the Southern Oscillation/El Niño. Mon. Weather Rev. 100: 354-384. http://dx.doi.org/10.1175/15200493(1982)110<0354:VITSST>2.0.CO;2

Rutllant J. 2004. Aspecto de la circulación a gran escala asociada al ciclo ENOS 1997-1999 y sus consecuencias en régimen de precipitación en Chile central. In: Avaria S, Carrasco J, Rutllant J, Yáñez E (eds.), El Niño-La Niña 1997-2000. Sus Efectos en Chile. CONA, Valparaíso, Chile pp. 61-76.

Rutllant J, Fuenzalida H. 1991. Synoptic aspects of the central Chile rainfall variability associated with the Southern Oscillation. Int. J. Climatol. 11: 63-76. http://dx.doi.org/10.1002/joc.3370110105

Savin SM. 1977. The history of the earth's surface temperature during the past 100 million years. Annu. Rev. Earth Planet. Sci. 5: 319-355. http://dx.doi.org/10.1146/annurev.ea.05.050177.001535

Shaffer G, Salinas S, Pizarro O, Vega A, Hormazabal S. 1995. Currents in the deep ocean off Chile $\left(30^{\circ} \mathrm{S}\right)$. Deep-Sea Res. 42: 425-436.

http://dx.doi.org/10.1016/0967-0637(95)99823-6 
Silva N, Rojas N, Fedele A. 2009. Water masses in the Humboldt Current System: Properties, distribution, and the nitrate deficit as a chemical water mass tracer for Equatorial Subsurface Water off Chile. Deep-Sea Res. (II) 56: 1004-1020. http://dx.doi.org/10.1016/j.dsr2.2008.12.013

Shackleton NJ. 1967. Oxygen isotope analyses and Pleistocene temperatures re-assessed. Nature 215: 15-17. http://dx.doi.org/10.1038/215015a0

Strub PT, Mesías JM, Montecino V, Rutllant J, Salinas S. 1998. Coastal ocean circulation off western South America. In: Robinson AR, Brink KH (eds). The Sea (Vol. 11). Wiley, New York, pp. 273-313.
Tappan H, Loeblich A. 1988. Foraminiferal evolution, diversification and extintion. J. Paleontol. 62: 695-713.

Thomas AC, Carr ME, Strub PT. 2001. Chlorophyll variability in eastern boundary currents. Geophys. Res. Lett. 28: 3421-3424. http://dx.doi.org/10.1029/2001GL013368

Watkins JM, Mix AC, Wilson J. 1998. Living planktic foraminifera in the central tropical Pacific Ocean: Articulating the equatorial 'cold tongue' during La Niña, 1992. Mar. Micropaleontol. 33: $157-174$.

http://dx.doi.org/10.1016/S0377-8398(97)00036-4

Received July 2012, received in revised form January 2013, accepted February 2013. 